
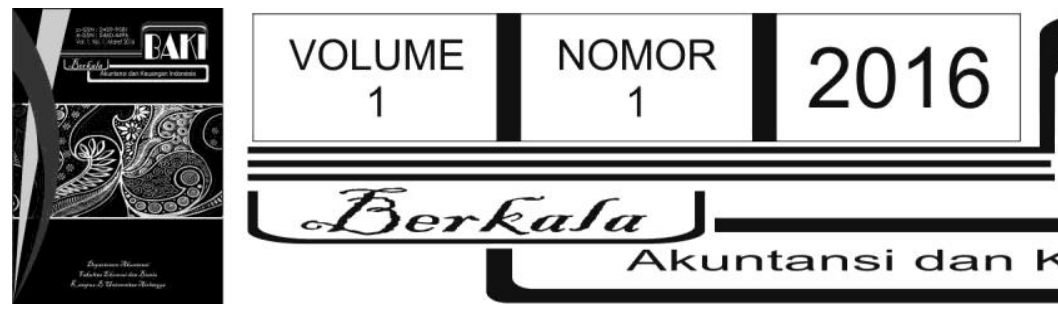

BerkataJ

Akuntansi dan Keuangan Indonesia

\title{
PERAN STRUKTUR CORPORATE GOVERNANCE DALAM TINGKAT KEPATUHAN PENGUNGKAPAN WAJIB PERIODE SETELAH KONVERGENSI IFRS (Studi pada Perusahaan Manufaktur yang Terdaftar di Bursa Efek Indonesia)
}

\author{
Barbara Gunawan*, Eka Riana Hendrawati \\ *Universitas Muhammadiyah Yogyakarta \\ *barbaragunawan@yahoo.co.id
}

INFO ARTIKEL

Histori Artikel:

Tanggal Masuk 5 Oktober 2015

Tanggal Diterima 8 Maret 2016

Tersedia Online 31 Maret 2016

Kata Kunci:

mekanisme corporate

governance;

tingkat kepatuhan

pengungkapan wajib periode

setelah konvergensi IFRS;

perusahaan manufaktur

\begin{abstract}
A B STRAK
Penelitian ini bertujuan untuk menguji tingkat kepatuhan pengungkapan wajib periode setelah konvergensi IFRS pada perusahaan manufaktur yang terdaftar di Bursa Efek Indonesia. Peneliti juga menguji pengaruh mekanisme corporate governance pada tingkat kepatuhan pengungkapan wajib. Mekanisme corporate governance diukur dengan jumlah anggota dewan komisaris, kepemilikan manajerial, proporsi komisaris independen, latar belakang komisaris utama, proporsi komisaris wanita, dan jumlah anggota komite audit. Pengumpulan data menggunakan metode purposive sampling pada perusahaan yang terdaftar di Bursa Efek Indonesia pada tahun 2012 dan 2013. Sampel yang digunakan adalah 36 perusahaan. Hasilnya menunjukkan bahwa variabel mekanisme corporate governance memengaruhi tingkat kepatuhan dengan konvergensi pengungkapan mandatory IFRS adalah jumlah komisaris independen dan jumlah anggota komie audit. Variabel kepemilikan manajerial, proporsi komisaris independen, latar belakang komisaris, dan proporsi komisaris wanita tidak berpengaruh terhadap tingkat kepatuhan pengungkapan wajib periode setelah konvergensi IFRS.
\end{abstract}

\section{Pendahuluan}

Penelitian ini bertujuan untuk mengetahui tingkat kepatuhan mandatory disclosure konvergensi International Financial Reporting Standard (IFRS) pada perusahaan manufaktur, serta untuk mengetahui pengaruh struktur corporate governance (CG) yang diukur dengan jumlah anggota dewan komisaris, kepemilikan manajerial, proporsi komisaris independen, latar belakang pendidikan, komisaris utama, proporsi komisaris wanita dan jumlah anggota komite audit terhadap tingkat kepatuhan mandatory disclosure tersebut. 
Tingkat persaingan yang semakin ketat dan kondisi ekonomi yang serba tidak menentu, mendorong setiap perusahaan untuk lebih transparan dalam mengungkapkan informasi tentang perusahaannya terutama bagi perusahaan go public. Penyusunan laporan keuangan harus didasari oleh standar akuntansi keuangan yang berlaku. Setiap negara memiliki peraturan standar keuangan yang berbeda. Perbedaan ini mencakup perlakuan, metode, penyajian, dan pelaporan. Perbedaan yang ada disetiap negara akan mempersulit para pengguna laporan keuangan dalam memahami laporan keuangan tersebut, sehingga untuk memudahkan pemahaman laporan keuangan diperlukan suatu standar yang sama antar negara yaitu Internasional Financial Reporting Standart (IFRS).

Dampak perekonomian dari penerapan IFRS pada akhir-akhir ini semakin disorotin banyak dunia. Penerapan IFRS dapat memberikan manfaat ekonomi yang sangat besar, sebagai cara untuk memudahkan pemahaman atas laporan keuangan secara internasional yang pemanfaatannya tidak hanya untuk para pelaku usaha yang bergerak dalam perusahaan go public namun manfaat yang diterima juga diperoleh para pengguna jasa keuangan. Selain itu, penerapan standar ini dapat meningkatkan arus investasi global melalui transparansi (Fajriansyah 2013). Beberapa tahun terakhir di Indonesia pengungkapan dan transparansi dalam laporan keuangan keuangan perusahaan menjadi isu penting di Indonesia (Utami et al., 2012).

Perusahaan go public dan multinasional di Indonesia diwajibkan untuk menerapkan standar akuntansi yang konvergen dengan IFRS untuk penyusunan laporan keuangan pada atau setelah 1 Januari 2012 (Gamayuni 2012 dalam Prawinandi et al., 2012). Setelah melewati tahap demi tahap konvergensi di Indonesia, IFRS menimbulkan efek positif maupun efek negatif terhadap perekonomian di Indonesia. Penerapan IFRS di Indonesia ini dilatarbelakangi oleh tuntutan global dunia usaha sehingga setiap perusahaan lebih meningkatkan kualitas informasi laporan keuangan dan laporan tahunan yang telah disusun serta bertujuan untuk terciptanya Good Corporate Governance (GCG). IFRS merupakan salah satu isu yang mendapat perhatian besar oleh pemerintah, jika semua perusahaan go public di Indonesia menyusun laporan keuangannya berdasarkan IFRS, tentunya akan membawa manfaat besar bagi pertumbuhan ekonomi di Indonesia serta dapat meningkatkan investor untuk berinvestasi di Indonesia. Investor yang berinvestasi atau menanamkan saham pada suatu perusahaan di Indonesia telah di atur oleh UU No. 40 Tahun 2007 tentang Perseroan Terbatas.

Penelitian ini dilatarbelakangi karena penelitian tentang tingkat kepatuhan mandatory disclosure konvergensi IFRS masih sedikit dilakukan di Indoensia, padahal IFRS sudah mulai di adopsi Indonesia 2008 hingga 2010, dilanjutkan tahun 2011 masa persiapan akhir IFRS, dan implementasi konvergensi IFRS dimulai tahun 2012.

Penelitian ini merupakan replikasi dari Prawinandi et al. (2012). Perbedaan dengan penelitian sebelumnya terletak pada penambahan variabel independen kepemilikan manajerial yang berasal dari penelitian Utami et al. (2012) dan diduga berpengaruh terhadap tingkat kepatuhan mandatory disclosure konvergensi IFRS. Dalam penelitian sebelumnya menggunakan sampel perusahaan jasa yang terdaftar di Bursa Efek Indonesia (BEI) tahun 2009-2010, sedangkan dalam penelitian ini 
menggunakan perusahaan manufaktur yang terdaftar di Bursa Efek Indonesia (BEI) pada tahun 2012-2013. Industri manufaktur digunakan sebagai objek penelitian karena memiliki populasi terbesar di Bursa Efek Indonesia.

\section{Kerangka Teori}

\subsection{Teori Stakeholders}

Teori stakeholders menyatakan bahwa perusahaan bukanlah entitas yang hanya beroperasi untuk kepentingan sendiri, namun harus mampu memberikan manfaat bagi stakeholders-nya (pemegang saham, kreditor, konsumen, supplier, pemerintah, masyarakat, dan pihak lain). Dengan demikian, keberadaan suatu perusahaan sangat dipengaruhi oleh dukungan yang diberikan stakeholders kepada perusahaan tersebut (Ghozali dan Chariri 2007).

\subsection{Teori Keagenan (Agency Theory)}

Teori agensi merupakan teori yang mengungkapkan kontrak antara principal dengan agent. Darmawati et al. (2005) dalam Sagala (2014) mengungkapkan bahwa inti dari hubungan keagenan adalah adanya pemisahan antara kepemilikan (principal/investor) dan pengendalian (agent/manajer) kepemilikan diwakili oleh investor yang mendelegasikan kewenangan kepada agen dalam hal ini manajer untuk mengelola kekayaan investor. Investor memiliki harapan bahwa dengan mendelegasikan wewenang pengelolaan tersebut, mereka akan memperoleh keuntungan dengan bertambahnya kekayaan dan kemakmuran investor (Sagala 2014).

\subsection{Mandatory Disclosure Konvergensi IFRS}

Pengungkapan wajib merupakan pengungkapan minimum yang disyaratkan oleh standar akuntansi yang berlaku (Suwardjono 2005). Menurut Suhardjanto dan Miranti (2009), terdapat 2 sifat pengungkapan yaitu pengungkapan wajib (mandatory disclosure) dan pengungkapan sukarela (voluntary disclosure). Mandatory disclosure bertujuan untuk memenuhi kebutuhan informasi pengguna laporan keuangan, memastikan pengendalian kualitas kinerja melalui ketaatan terhadap hukum dan standar akuntansi yang berlaku (Adina dan lon 2008 dalam Prawinandi et al., 2012). Peraturan mengenai mandatory disclosure di Indonesia telah diatur oleh BAPEPAM-LK melalui Peraturan No. VIII.G.7 tentang Pedoman Penyajian Laporan Keuangan.

Terdapat beberapa istilah yang digunakan berkaitan dengan penerapan IFRS. Konvergensi IFRS memiliki arti menyelaraskan standar akuntansi yang dipakai di suatu negara dengan IFRS untuk memperkecil perbedaan dari keduanya (Prawinandi et al., 2012). Adopsi IFRS artinya mengambil bahasa pelaporan keuangan internasional untuk diterapkan kedalam bahasa pelaporan keuangan suatu negara, sedangkan harmonisasi artinya proses untuk meningkatkan komparabilitas laporan keuangan dengan menentukan batasan-batasan seberapa besar praktik-praktik tersebut dapat 
beragam (Perramon dan Amat 2007 dalam Prawinandi et al., 2012). Perusahaan go public dan multinasional di Indonesia diwajibkan untuk menerapkan standar akuntansi yang konvergen dengan IFRS untuk penyusunan laporan keuangan pada atau setelah 1 Januari 2012 (Gamayuni 2012 dalam Prawinandi et al., 2012).

\subsection{Struktur Corporate Governance}

Corporate governance adalah seperangkat peraturan yang mengatur hubungan antara pemegang saham, pengurus (pengelola) perusahaan, pihak kreditur, pemerintah, karyawan, serta para pemegang kepentingan internal dan eksternal lainnya yang berkaitan dengan hak-hak dan kewajiban mereka atau dengan kata lain suatu sistem yang mengendalikan perusahaan (FCGI 2001 dalam Prawinandi et al., 2012).

FCGI (2001) dalam Prawinandi et al. (2012) menjelaskan bahwa Indonesia menganut sistem dua tingkat atau Two Tiers System, artinya perusahaan mempunyai dua badan terpisah, yaitu dewan pengawas (dewan komisaris) dan dewan manajemen (dewan direksi). Dari penjelasan di atas dapat disimpulkan bahwa struktur corporate governance merupakan suatu susunan organ di dalam perusahaan yang menjalankan fungsi tata kelola sebagai pihak pengawas dan pihak yang menjalankan perusahaan.

\subsection{Jumlah Anggota Dewan Komisaris dan Mandatory Disclosure}

Tugas utama dewan komisaris adalah mengawasi dan mengevaluasi pembuatan kebijakan dan pelaksanaan kebijakan oleh direksi dalam menjalankan perusahaan, serta memberi nasehat atau masukan kepada dewan direksi (Muntoro 2006). Semakin besar dewan komisaris didalam perusahaan maka pengawasan, pengevaluasian, dan pelaksanaan kebijakan oleh direksi semakin berkualitas sesuai dengan tujuan yang ingin dicapai perusahaan sehingga akan mempengaruhi tingkat kepatuhan mandatory disclosure konvergensi IFRS.

Penelitian Kent dan Stewart (2008) serta Al-Akra et al. (2010) dalam Prawinandi et al. (2012) menunjukkan bahwa jumlah anggota dewan komisaris berpengaruh positif terhadap tingkat kepatuhan pengungkapan wajib IFRS. Berdasarkan uraian tersebut, hipotesis yang dikembangkan adalah:

$\mathrm{H}_{1}$ : Jumlah anggota dewan komisaris berpengaruh positif terhadap tingkat mandatory disclosure konvergensi IFRS.

\subsection{Kepemilikan Manajerial dan Mandatory Disclosure}

Kepemilikan manajerial dapat mensejajarkan kepentingan manajemen dan pemegang saham akan memperoleh manfaat langsung dari keputusan yang diambil serta menanggung kerugian sebagai konsekuensi dari pengambilan keputusan yang salah (Wahyudi dan Pawestri 2006 dalam Sagala 2014). Kepemilikan manajerial dianggap sebagai salah satu faktor yang berpengaruh 
terhadap kepatuhan perusahaan dalam melakukan transparansi. Semakin besar kepemilikan manajerial dalam perusahaan maka tingkat monitoring semakin kuat sehingga manajer akan lebih meningkatkan tingkat kepatuhan mandatory disclosure sesuai dengan syarat yang berlaku.

Penelitian Nasir dan Abdullah (2004) serta Clemente dan Labat (2005) dalam Utami et al. (2012) menunjukkan bahwa kepemilikan manajerial berpengaruh positif terhadap tingkat kepatuhan pengungkapan wajib. Penelitian Utami et al. (2012) menunjukkan bahwa kepemilikan manajerial berpengaruh signifikan positif terhadap tingkat kepatuhan pengungkapan wajib IFRS. Berdasarkan uraian tersebut, hipotesis yang dapat dikembangkan adalah:

$\mathrm{H}_{2}$ : Kepemilikan manajerial berpengaruh positif terhadap tingkat kepatuhan mandatory disclosure konvergensi IFRS.

\subsection{Proporsi Komisaris Indepeden dan Mandatory Disclosure}

Suhardjanto dan Afni (2009) menjelaskan bahwa komisaris independen adalah komisaris yang berasal dari luar perusahaan. Dewan komisaris independen sangat berpengaruh terhadap pengambilan keputusan perusahaan, hilangnya independensi komisaris dalam pengambilan keputusan akan mengurangi objektivitas dalam pengambilan keputusan perusahaan (Alijoyo dan Zaini 2004 dalam Fajriansyah 2013). Semakin besarnya proporsi komisaris independen maka proses pengawasan yang dilakukan dewan ini makin berkualitas dengan makin banyaknya pihak independen dalam perusahaan yang menuntut adanya transparansi dalam pelaporan pengungkapan perusahaan.

Penelitian Huafang dan Jianguo (2007) dalam Prawinandi et al. (2012) menunjukkan bahwa proporsi komisaris independen berpengaruh positif terhadap tingkat pengungkapan dalam laporan keuangan. Penelitian Prawinandi et al. (2012) menunjukkan bahwa proporsi komisaris independen berpengaruh signifikan positif terhadap mandatory disclosure konvergensi IFRS Berdasarkan uraian tersebut, hipotesis yang dikembangkan adalah:

$\mathrm{H}_{3}$ : Proporsi komisaris independen berpengaruh positif terhadap mandatory disclosure konvergensi IFRS.

\subsection{Latar Belakang Komisaris Utama dan Mandatory Disclosure}

Tugas komisaris utama adalah mengkoordinasikan kegiatan dewan komisaris, jika komisaris utama memiliki latar belakang pendidikan ekonomi dan bisnis, diharapkan koordinasi dewan komisaris menjadi lebih efektif. (KNKG 2006 dalam Prawinandi et al., 2012). Latar belakang pendidikan komisaris utama mempengaruhi keputusan dan masukan yang diberikan kepada dewan direksi (Suhardjanto dan Afni 2009). Komisaris utama yang memiliki latar belakang pendidikan ekonomi dan bisnis akan lebih memahami tentang pengelolaan perusahaan dan pengambilan keputusan bisnis, sehingga dapat mempengaruhi tingkat kepatuhan mandatory disclosure konvergensi IFRS. 
Penelitian Suhardjanto dan Afni (2009) menunjukkan bahwa latar belakang pendidikan dewan komisaris merupakan faktor yang menentukan social disclosure pada annual report perusahaan. Penelitian Kharis dan Suhardjanto (2012) menunjukkan bahwa latar belakang komisaris utama berpengaruh signifikan positif terhadap ketaatan pengungkapan wajib. Berdasarkan uraian tersebut, hipotesis yang dikembangkan adalah:

$\mathrm{H}_{4}$ : Latar belakang pendidikan komisaris utama berpengaruh positif terhadap tingkat kepatuhan mandatory disclosure konvergensi IFRS.

\subsection{Proporsi Komisaris Wanita dan Mandatory Disclosure}

Komisaris wanita akan meningkatkan monitoring terhadap kinerja perusahaan karena wanita memiliki sikap kehati-hatian yang sangat tinggi, cenderung menghindari risiko, dan lebih teliti dalam melakukan pengawasan dibandingkan pria (Kusumastuti et al., 2007). Dengan semakin banyaknya komisaris wanita akan lebih meningkatkan kepatuhan dalam mengungkapkan kondisi perusahaan sesuai dengan konvergensi IFRS.

Penelitian Feijo et al. (2012) dalam Prawinandi et al. (2012) menunjukkan bahwa komisaris wanita berpengaruh terhadap pengungkapan corporate social responsibility (CSR). Berdasarkan uraian tersebut, hipotesis yang dikembangkan adalah:

$\mathrm{H}_{5}$ : Proporsi komisaris wanita berpengaruh positif terhadap tingkat kepatuhan mandatory disclosure konvergensi IFRS.

\subsection{Jumlah Anggota Komite Audit dan Mandatory Disclosure}

Komite audit memiliki peran dalam mengawasi pihak manajemen (agen) agar tidak melakukan tindakan yang dapat menguntungkan dirinya sendiri sehingga dapat merugikan pemilik perusahaan (prinsipal). Komite audit juga dipandang sebagai alat untuk menghindari kecurangan dalam pelaporan keuangan dan memonitoring kinerja manajemen. Semakin besar komite audit didalam perusahaan akan meningkatkan pengawasan terhadap auditor dan kinerja manajemen sehingga pelaporan keuangan semakin berkualitas serta akan mempengaruhi tingkat kepatuhan mandatory disclosure perusahaan sesuai dengan konvergensi IFRS.

Penelitian Cety dan Suhardjanto (2010) dalam Suhardjanto et al. (2012) menunjukkan anggota komite audit berpengaruh positif terhadap kinerja perusahaan, termasuk dalam pengungkapan informasi. Penelitian Kent dan Stewart (2008) dalam Prawinandi et al. (2012) menunjukkan bahwa jumlah anggota komite audit mempengaruhi kualitas pengungkapan dalam laporan keuangan yang disusun berdasarkan IFRS, dimana di dalamnya termasuk mandatory disclosure. Berdasarkan uraian tersebut, hipotesis yang dikembangkan adalah:

$\mathrm{H}_{6}$ : Jumlah anggota komite audit berpengaruh positif terhadap tingkat kepatuhan mandatory disclosure konvergensi IFRS. 


\section{Metode Penelitian}

\subsection{Jenis Data}

Data merupakan bagian jumlah dan karakteristik yang dimiliki oleh populasi, dijadikan obyek penelitian dan teknik pengambilan data historis. Data yang digunakan dalam penelitian ini adalah data sekunder. Data sekunder diambil dari annual report perusahaan manufaktur yang terdaftar di BEl tahun 2012-2013.

\subsection{Teknik Pengambilan Sampel}

Sampel dalam penelitian ini adalah perusahaan manufaktur yang terdaftar di BEI 2012-2013. Metode pengambilan data yang digunakan dalam penelitian ini adalah purposive sampling, yaitu pemilihan sampel tidak secara acak tetapi menggunakan pertimbangan-pertimbangan dan kriteriakriteria yang telah ditentukan oleh peneliti. Kriteria dalam pengambilan sampel penelitian ini sebagai berikut:

a. Perusahaan manufaktur yang terdaftar di Bursa Efek Indonesia (BEI) secara berturut-turut untuk tahun 2012-2013.

b. Perusahaan yang mempublikasikan laporan keuangannya secara lengkap.

c. Perusahaan yang memiliki kepemilikan saham oleh manajerial perusahaan.

d. Perusahaan yang memiliki data-data yang lengkap terkait dengan variabel penelitian.

\subsection{Operasional Variabel Penelitian}

a. Variabel Dependen (Tingkat Kepatuhan Mandatory Disclosure Konvergensi IFRS)

Variabel dependen dalam penelitian ini adalah tingkat kepatuhan mandatory disclosure konvergensi IFRS. Identifikasi item pengungkapan menggunakan checklist BAPEPAM LK-2012, itemitem yang dipilih dari checklist sesuaikan dengan PSAK yang berlaku di Indonesia yang wajib diterapkan untuk periode 2012-2013 pada perusahaan manufaktur yang konvergensi IFRS. Total item maksimum yang wajib diungkapkan setiap perusahaan tahun 2012 dan 2013 masing-masing sama sebanyak 155 item.

Pengungkapan wajib diukur dengan menggunakan teknik scoring, yakni jika item tersebut dapat diterapkan (applicable) dalam perusahaan dan diungkapkan diberi skor 1 dan jika tidak diungkapkan diberi skor 0, serta N/A jika item tersebut tidak dapat diterapkan dalam perusahaan (Apostolou dan Nanopoulos 2009 dalam Prawinandi et al., 2012). Tingkat kepatuhan mandatory disclosure konvergensi IFRS dalam penelitian ini diperoleh dengan menggunakan metode Partial Compliance Weighted (PC Weighted), yakni menjumlahkan item yang diungkapkan oleh perusahaan kemudian membagi hasilnya dengan total item yang applicable dalam tiap perusahaan (Tsalavoutas et al., 2008 dalam Prawinandi et al., 2012). 


\section{MANSCORE BY $=\frac{\sum S C O R E ~ i B Y}{\sum M A X i B Y}$}

b. Variabel Independen (Struktur Corporate Governance)

1) Jumlah Anggota Dewan Komisaris

Jumlah anggota dewan komisaris diukur dengan jumlah komisaris dari pihak yang terafiliasi (memiliki hubungan, salah satunya pihak internal perusahaan) dan tidak terafiliasi (tidak memiliki hubungan) dengan perusahaan (KNKG 2006 dalam Prawinandi et al., 2012).

2) Kepemilikan Manajerial

Indikator yang digunakan untuk mengukur kepemilikan manajerial adalah persentase jumlah saham yang dimiliki pihak manajemen dari seluruh modal saham perusahaan yang beredar (Suryani 2010 dalam Utami et al., 2012).

3) Proporsi Komisaris Independen

Proporsi komisaris independen dapat diukur dengan membagi jumlah anggota komisaris yang berasal dari luar perusahaan dengan jumlah keseluruhan anggota dewan komisaris (Haniffa dan Cooke 2005 dalam Prawinandi et al., 2012).

4) Latar Belakang Komisaris Utama

Latar belakang pendidikan komisaris utama adalah latar belakang pendidikan ekonomi dan bisnis yang dimiliki oleh komisaris utama (Suhardjanto dan Afni 2009). Latar belakang pendidikan ini diukur dengan variabel dummy, jika komisaris utama memiliki latar belakang pendidikan ekonomi atau bisnis diberi kode 1, selain ekonomi atau bisnis diberi kode 0 (Suhardjanto dan Miranti 2009).

5) Proporsi Komisaris Wanita

Proporsi komisaris wanita dapat diukur dengan membandingkan jumlah anggota komisaris wanita dengan jumlah seluruh anggota dewan komisaris (Nalikka 2009 dalam Prawinandi et al., 2012).

6) Jumlah Anggota Komite Audit

Jumlah anggota komite audit dapat diukur dengan menjumlahkan banyaknya anggota komite audit dalam perusahaan (Zaluki dan Husin 2009 dalam Prawinandi et al., 2012).

\subsection{Metode Analisa Data}

Dalam penelitian ini, analisis data yang digunakan adalah analisa pengujian statistik deskriptif dan analisa pengujian hipotesis. Metode statistik yang digunakan untuk menguji hipotesis adalah regresi berganda. Model analisisnya adalah sebagai berikut:

MANDSCORE $=\beta_{0}+\beta_{1} J A D K+\beta_{2} K M+\beta_{3} P K I+\beta_{4} L B K U+\beta_{5} P K W+\beta_{6} J A K A+\varepsilon$

Keterangan:

MANDSCORE = Mandatory Disclosure 


$\begin{array}{ll}\text { JADK } & =\text { Jumlah Anggota Dewan Komisaris } \\ \text { KM } & =\text { Kepemilikan Manajerial } \\ \text { PKI } & =\text { Proporsi Komisaris Independen } \\ \text { LBKU } & =\text { Latar Belakang Komisaris Utama } \\ \text { PKW } & =\text { Proporsi Komisaris Wanita } \\ \text { JAKA } & =\text { Jumlah Anggota Komite Audit } \\ B & =\text { Koefisien Regresi Berganda } \\ \varepsilon & =\text { error item }\end{array}$

\section{HASIL PENELITIAN DAN PEMBAHASAN}

\subsection{Analisis Deskriptif}

Descriptive Statistics

\begin{tabular}{|l|r|r|r|r|r|}
\hline & \multicolumn{1}{|c|}{$\mathrm{N}$} & \multicolumn{1}{c|}{ Minimum } & Maximum & \multicolumn{1}{c|}{ Mean } & Std. Deviation \\
\hline JADK & 36 & 2.00 & 7.00 & 4.0833 & 1.33898 \\
KM & 36 & .01 & 79.68 & 11.0881 & 22.14501 \\
PKI & 36 & .29 & .60 & .3753 & .08020 \\
LBKU & 36 & .00 & 1.00 & .3333 & .47809 \\
PKW & 36 & .14 & .67 & .3189 & .15425 \\
JAKA & 36 & 2.00 & 3.00 & 2.8056 & .40139 \\
MANDSCORE & 36 & 69.03 & 97.42 & 86.9708 & 6.22958 \\
Valid N (listwise) & 36 & & & & \\
\hline
\end{tabular}

Variabel JADK memiliki nilai minimum sebesar 2,00; nilai maksimum sebesar 7,00; nilai rata-rata (mean) sebesar 4,0833; dan simpangan baku (standar deviation) sebesar 1,33898.Variabel KM memiliki nilai minimum sebesar 0,01 ; nilai maksimum sebesar 79,68; nilai rata-rata (mean) sebesar 11,0881; dan simpangan baku (standar deviation) sebesar 22,14501. Variabel PKI memiliki nilai minimum sebesar 0,29 ; nilai maksimum sebesar 0,60 ; nilai rata-rata (mean) sebesar 0,3753 ; dan simpangan baku (standar deviation) sebesar 0,08020. Variabel LBKU memiliki nilai minimum sebesar 0,00; nilai maksimum sebesar 1,00; nilai rata-rata (mean) sebesar 0,3333; dan simpangan baku (standar deviation) sebesar 0,47809. Variabel PKW memiliki nilai minimum sebesar 0,14; nilai maksimum sebesar 0,67; nilai rata-rata (mean) sebesar 0,3189; dan simpangan baku (standar deviation) sebesar 0,15425. Variabel JAKA memiliki nilai minimum sebesar 2,00; nilai maksimum sebesar 3,00; nilai rata-rata (mean) sebesar 2,8056; dan simpangan baku (standar deviation) sebesar 0,40139. Variabel Mandatory Disclosure memiliki nilai minimum sebesar 69,03; nilai maksimum sebesar 97,42; nilai rata-rata (mean) sebesar 86,9708; dan simpangan baku (standar deviation) sebesar 6,22958. 


\subsection{Uji Hipotesis}

Coefficients

\begin{tabular}{|c|c|c|c|c|c|c|}
\hline \multirow[b]{2}{*}{ Mod } & & \multicolumn{2}{|c|}{$\begin{array}{c}\text { Unstandardiz ed } \\
\text { Coefficients }\end{array}$} & \multirow{2}{*}{$\begin{array}{c}\begin{array}{c}\text { Standardized } \\
\text { Coefficients }\end{array} \\
\text { Beta }\end{array}$} & \multirow[b]{2}{*}{$t$} & \multirow[b]{2}{*}{ Sig. } \\
\hline & & B & Std. Error & & & \\
\hline \multirow[t]{7}{*}{1} & (Cons tant) & 27.748 & 6.755 & & 4.108 & .000 \\
\hline & JADK & 2.826 & 1.229 & .557 & 2.299 & .029 \\
\hline & $\mathrm{KM}$ & -.005 & .055 & -.016 & -.092 & .927 \\
\hline & PKI & -20.116 & 13.084 & -.275 & -1.537 & . 135 \\
\hline & LBKU & 2.848 & 2.944 & .192 & .967 & .341 \\
\hline & PKW & 13.618 & 10.129 & .329 & 1.344 & .189 \\
\hline & JAKA & 10.180 & 2.726 & .684 & 3.735 & .001 \\
\hline
\end{tabular}

a. Dependent Variable: MANDSCORE

Berdasarkan pengujian pada tabel 4.10 dapat dirumuskan regresi sebagai berikut:

MANDSCORE $=27,748+2,826$ JADK - 0,005 KM - 20,116 PKI + 2,848 LBKU + 13,618 PKW + $10,180 \mathrm{JAKA}+6,755$

\section{a. Pengujian Hipotesis Satu $\left(\mathrm{H}_{1}\right)$}

Variabel jumlah anggota dewan komisaris mempunyai nilai sig 0,029 $<\alpha(0,05)$ dan arah koefisien regresi positif 2,826 berarti jumlah anggota dewan komisaris berpengaruh signifikan positif terhadap tingkat kepatuhan mandatory disclosure konvergensi IFRS. Dengan demikian hipotesis satu $\left(\mathrm{H}_{1}\right)$ diterima.

Hasil hipotesis jumlah anggota dewan komisaris menunjukkan bahwa semakin besar dewan komisaris disuatu perusahaan akan meningkatkan pengawasan, pengevaluasian, dan pelaksanaan kebijakan oleh direksi semakin berkualitas sesuai dengan tujuan yang ingin dicapai perusahaan, serta semakin berfungsinya corporate governance dalam meningkatkan kepatuhan mandatory disclosure konvergensi IFRS.

Hasil penelitian ini mendukung penelitian Kent dan Stewart (2008) dalam Prawinandi et al. (2012) serta penelitian Al-Akra et al. (2010) dalam Prawinandi et al. (2012) menunjukkan bahwa jumlah anggota dewan komisaris berpengaruh positif terhadap tingkat kepatuhan pengungkapan wajib IFRS.

\section{b. Pengujian Hipotesis Dua $\left(\mathrm{H}_{2}\right)$}

Variabel kepemilikan manajerial mempunyai nilai sig $0,927>\alpha(0,05)$ dan arah koefisien regresi negatif 0,005 berarti kepemilikan manajerial tidak berpengaruh terhadap tingkat kepatuhan mandatory disclosure konvergensi IFRS. Dengan demikian hipotesis dua $\left(\mathrm{H}_{2}\right)$ ditolak.

Hasil hipotesis kepemilikan manajerial menunjukkan bahwa semakin tinggi presentase kepemilikan saham yang dimiliki pihak manajerial tidak dapat menjamin kontribusi fungsi pengawasan dapat berjalan dengan baik. Hal ini didasarkan pada kondisi di Indonesia, dimana masih sedikit pihak manajemen yang memiliki saham diperusahaan, sehingga tidak berpengaruh terhadap tingkat kepatuhan mandatory disclosure konvergensi IFRS. 
Hasil penelitian ini mendukung penelitian Fajriansyah (2013) yang menunjukkan bahwa kepemilikan manajerial tidak berpengaruh terhadap tingkat kepatuhan pengungkapan wajib IFRS. Akan tetapi tidak mendukung penelitian Utami et al. (2012) yang menunjukkan bahwa kepemilikan manajerial berpengaruh positif terhadap pengungkapan wajib IFRS.

C. Pengujian Hipotesis Tiga $\left(\mathrm{H}_{3}\right)$

Variabel proporsi komisaris independen mempunyai nilai sig 0,135 $>\alpha(0,05)$ dan arah koefisien regresi negatif 20,116 berarti proporsi komisaris independen tidak berpengaruh terhadap tingkat kepatuhan mandatory disclosure konvergensi IFRS. Dengan demikian hipotesis tiga $\left(\mathrm{H}_{3}\right)$ ditolak.

Hasil hipotesis proporsi komisaris independen menunjukkan bahwa besarnya komisaris independen disuatu perusahaan tidak memiliki hubungan terhadap pengungkapan. Hal ini didasarkan pada masih minimnya perusahaan yang memiliki komisaris independen sehingga belum cukup tinggi untuk membuat komisaris independen tersebut mendominasi kebijakan yang diambil oleh dewan komisaris, sehingga berapapun jumlah komisaris independen disuatu perusahaan tidak berpengaruh terhadap mandatory disclosure konvergensi IFRS.

Hasil penelitian ini mendukung penelitian Kharis dan Suhardjanto (2012) serta Utami et al. (2012) yang menunjukkan bahwa proporsi komisaris independen tidak berpengaruh terhadap pengungkapan wajib IFRS. Akan tetapi tidak mendukung penelitian Prawinandi et al. (2012) yang menunjukkan bahwa proporsi komisaris independen berpengaruh terhadap tingkat kepatuhan mandatory disclosure konvergensi IFRS.

\section{d. Pengujian Hipotesis Empat $\left(\mathrm{H}_{4}\right)$}

Variabel latar belakang komisaris utama mempunyai nilai sig 0,341 > $(0,05)$ dan arah koefisien regresi positif 2,848 berarti latar belakang komisaris utama independen tidak berpengaruh terhadap tingkat kepatuhan mandatory disclosure konvergensi IFRS. Dengan demikian hipotesis empat $\left(\mathrm{H}_{4}\right)$ ditolak.

Hasil hipotesis latar belakang komisaris utama menunjukkan bahwa latar belakang komisaris utama dalam suatu perusahaan tidak berpengaruh dalam pengambilan keputusan atau dalam memanajemen suatu perusahaan, karena komisaris utama lebih mengutamakan bagaimana dia berani dalam pengambilan keputusan dengan berbagai resiko, berinovasi, serta dapat mengembangkan perusahaan sesuai dengan kondisi pasar.

Hasil penelitian ini mendukung penelitian Prawinandi et al. (2012) yang menunjukkan bahwa latar belakang komisaris utama tidak berpengaruh terhadap tingkat kepatuhan mandatory disclosure konvergensi IFRS. Akan tetapi tidak mendukung penelitian Suhardjanto dan Afni (2009) serta Kharis dan Suhardjanto (2012) yang menunjukkan bahwa latar belakang berpengaruh positif terhadap pengungkapan. 
e. Pengujian Hipotesis Lima $\left(\mathrm{H}_{5}\right)$

Variabel proporsi komisaris wanita mempunyai nilai sig $0,189>\alpha(0,05)$ dan arah koefisien regresi positif 13,618 berarti proporsi komisaris wanita tidak berpengaruh terhadap tingkat kepatuhan mandatory disclosure konvergensi IFRS. Dengan demikian hipotesis lima $\left(\mathrm{H}_{5}\right)$ ditolak.

Hasil hipotesis proporsi komisaris wanita menunjukkan bahwa berapapun jumlah komisaris wanita tidak akan mempengaruhi tingkat mandatory disclosure dalam perusahaan. Hal ini didasarkan pada kondisi Indonesia yang menganut sistem kekerabatan patrilineal (garis keturunan ayah) dimana pria dianggap sebagai pemegang kontrol dan pengambil keputusan utama (Anjani 2009 dalam Prawinandi et al., 2012).

Hasil penelitian ini mendukung penelitian Prawinandi et al. (2012) yang menunjukkan bahwa proporsi komisaris wanita tidak berpengaruh terhadap tingkat kepatuhan mandatory disclosure konvergensi IFRS. Akan tetapi tidak mendukung penelitian Feijo et al. (2012) dalam Prawinandi et al. (2012) yang menunjukkan bahwa komisaris wanita berpengaruh terhadap pengungkapan CSR.

\section{f. Pengujian Hipotesis Enam $\left(\mathrm{H}_{6}\right)$}

Variabel jumlah anggota komite audit mempunyai nilai sig 0,001 < $\alpha(0,05)$ dan arah koefisien regresi positif 10,180 berarti jumlah anggota komite audit berpengaruh terhadap tingkat kepatuhan mandatory disclosure konvergensi IFRS. Dengan demikian hipotesis enam $\left(\mathrm{H}_{6}\right)$ diterima.

Hasil hipotesis jumlah anggota komite menunjukkan bahwa semakin besar jumlah anggota komite audit di dalam perusahaan akan meningkatkan pengawasan terhadap auditor dan kinerja manajemen sehingga tidak terjadi kecurangan dalam penyusunan laporan keuangan sehingga laporan keuangan yang dihasilkan semakin berkualitas serta akan lebih cenderung patuh dalam meningkatkan mandatory disclosure konvergensi IFRS.

Penelitian ini mendukung penelitian Cety dan Suhardjanto (2010) dalam Suhardjanto et al. (2012) yang menunjukkan anggota komite audit berpengaruh positif terhadap kinerja perusahaan, termasuk dalam pengungkapan informasi, serta penelitian Kent dan Stewart (2008) dalam Prawinandi et al. (2012) yang menunjukkan bahwa jumlah anggota komite audit mempengaruhi kualitas pengungkapan dalam laporan keuangan yang disusun berdasarkan IFRS, dimana di dalamnya termasuk mandatory disclosure.

\section{Kesimpulan dan Saran}

Berdasarkan analisis dan pengujian data dalam penelitian ini, dapat ditarik kesimpulan bahwa variabel jumlah anggota dewan komisaris dan jumlah anggota komite audit berpengaruh positif terhadap tingkat kepatuhan mandatory disclosure konvergensi IFRS, sedangkan variabel kepemilikan manajerial, proporsi komisaris independen, latar belakang komisaris utama, dan proporsi komisaris wanita tidak berpengaruh terhadap tingkat kepatuhan mandatory disclosure konvergensi IFRS. 
Adapun keterbatasan pada penelitian ini yaitu sampel penelitian hanya 36 perusahaan, periode penelitian 2 tahun, objek penelitian perusahaan manufaktur sehingga tidak bisa digeneralisasikan, penelitian menggunakan variabel proporsi komisaris wanita dan kepemilikan manajerial yang dapat mengurangi sampel penelitian karena tidak semua perusahaan memiliki komisaris wanita dan manajer memiliki saham diperusahaan tersebut. Saran untuk penelitian yang akan datang dapat menambahkan periode penelitian, mengubah objek penelitian, mengganti variabel komisaris wanita dan kepemilikan manajerial dengan variabel corporate governance yang lain.

\section{Daftar Pustaka}

Badan Pengawas Pasar Modal. 2013. http://www.bapepam.go.id/pasar_modal/publikasi_pm (Diakses September 2013).

Chariri, A., dan I. Ghozali. 2007. Teori Akuntansi. Semarang: Universitas Diponegoro Semarang.

Fajriansyah, F. 2013. Pengaruh Mekanisme Corporate Governance dan Ukuran Perusahaan terhadap Tingkat Pengungkapan Wajib IFRS. Skripsi. Yogyakarta: Universitas Muhammadiyah Yogyakarta.

Kharis, A., dan Suhardjanto. 2012. Corporate Governance dan Ketaatan Pengungkapan Wajib pada Badan Usaha Milik Daerah. Jurnal Keuangan dan Perbankan 16 (1): 37-44.

Kusumastuti, S., S. Supatmi, dan P. Sastra. 2007. Pengaruh Board Diversity terhadap Nilai Perusahaan dalam Perspektif Corporate Governance. Jurnal Akuntansi dan Keuangan 9 (2): 8898.

Muntoro, R. K. 2006. Membangun Dewan Komisaris yang Efektif. Jurnal Manajemen Usahawan Indonesia 36 (11): 9-14.

Prawinandi, W., D. Suhardjanto, dan H. Triatmoko. 2012. Peran Struktur Corporate Governance dalam Tingkat Kepatuhan Mandatory Disclosure Konvergensi IFRS. Proceeding Simposium Nasional Akuntansi XV. Banjarmasin.

Republik Indonesia. 2007. UU No. 40 Tahun 2007 Tentang Perseroan Terbatas. Jakarta.

Sagala, W. 2014. Faktor-faktor yang Berpengaruh Terhadap Environmental Disclosure. Skripsi. Yogyakarta: Universitas Muhammadiyah Yogyakarta.

Suhardjanto, D., dan A. N. Afni. 2009. Praktik Corporate Disclosure di Indonesia. Studi Empiris di Bursa Efek Indonesia. Jurnal Akuntansi 14 (2): 125-139.

Suhardjanto, dan L. Miranti. 2009. "Praktik Penerapan Indonesian Reporting Index dan Kaitannya dengan Karakteristik Perusahaan". Jurnal Akuntansi dan Auditing Indonesia (JAAl) 13 (1): 63-77.

Suhardjanto, D., A. Dewi, E. Rahmawati, dan Firazonia M. 2012. Peran Corporate Governance dalam Praktik Risk Disclosure pada Perbankan Indonesia. Jurnal Akuntansi dan Auditing 9 (1): 1-96.

Suwardjono. 2005. Teori Akuntansi: Perekayasaan Pelaporan Keuangan. Edisi III. Yogyakarta: BPFE.

Utami, W.D., D. Suhardjanto, dan S. Hartoko. 2012. Investigasi dalam Konvergensi IFRS Di Indonesia: Tingkat Kepatuhan Pengungkapan Wajib dan Kaitannya dengan Mekanisme Corporate Governance. Proceeding Simposium Nasional Akuntansi XV. Banjarmasin. 